US Army Corps

of Engineers

Construction Engineering

Research Laboratory

\title{
An Erosion-Based Land Classification System for Military Installations
}

by

Steven D. Warren

Victor E. Diersing

Pamela J. Thompson

William D. Goran

The universal soil loss equation (USLE) has been integrated with a geographic information system known as the Geographical Resources Analysis Support System (GRASS) to create a land classification system for use by military trainers and land managers to minimize the environmental impacts of military training activities. The USLE provides an estimate of current average annual sheet and rill erosion based upon factors representing climate, soil erodibility, topography, cover, and conservation support practices. The erosion estimate is compared to erosion tolerance values to produce an expression of the current erosion status. An index of inherent site erodibility is also achieved through manipulation of the USLE. Based on published soil surveys, satellite image$r y$, and ground-truth vegetation transects, data layers are created within GRASS for each of the component factors of the USLE. Appropriate mathematical operations are performed with the data layers, and color-coded maps are produced that represent the erosion status and erodibility index for each $50-\mathrm{m} \times 50-\mathrm{m}$ area of soil surface. These maps aid military trainers and land managers in scheduling appropriate kinds and intensities of military training activities.

Approved for public release; distribution is unlimited.

\author{
For Reference
}

Not to be taken from this room 
The contents of this report are not to be used for advertising, publication, or promotional purposes. Citation of trade names does not constitute an official indorsement or approval of the use of such commercial products. The findings of this report are not to be construed as an official Department of the Army position, unless so designated by other authorized documents. 


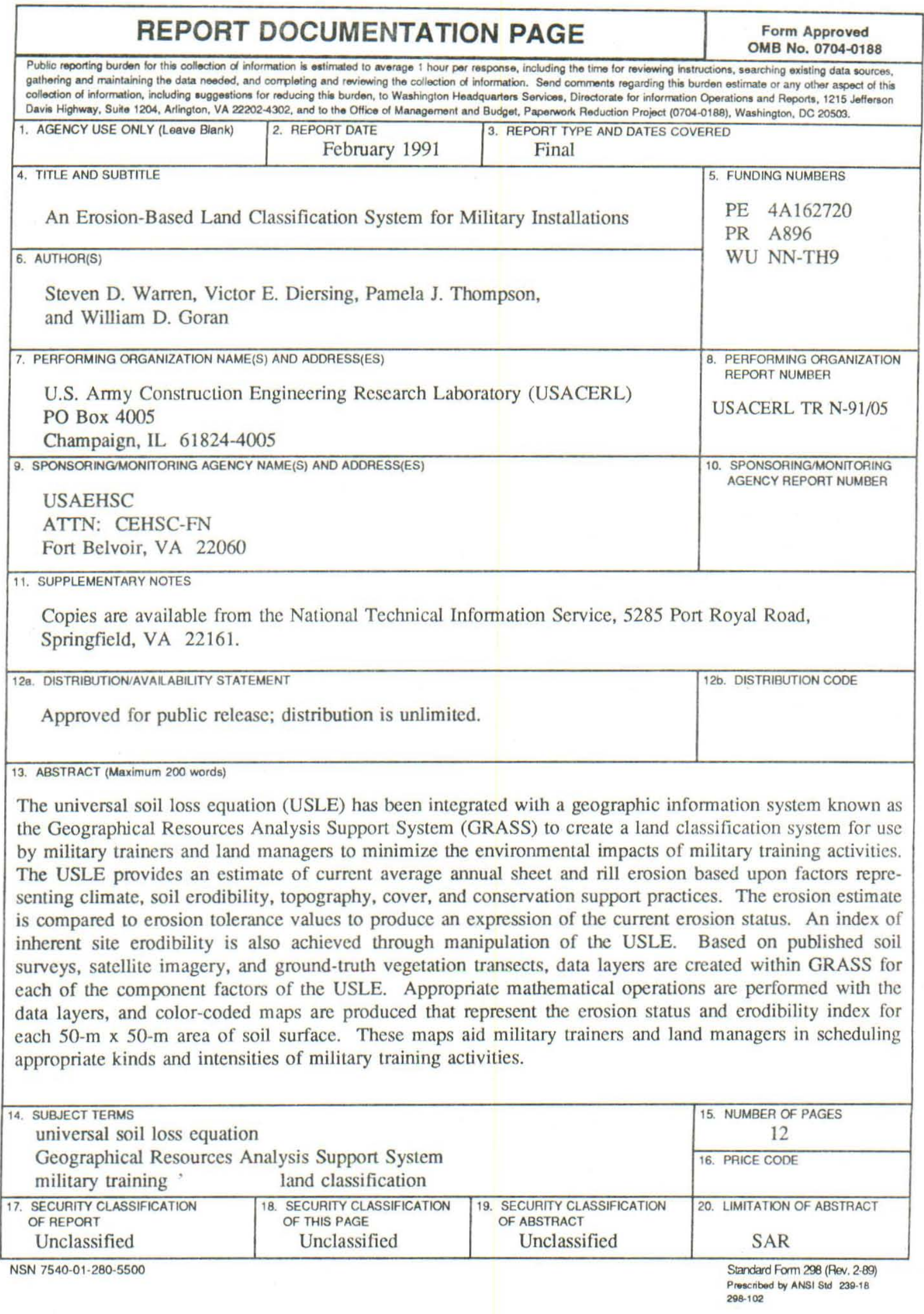




\section{FOREWORD}

This is a reprint, with permission, of an article published in Environmental Management, Vol 13, No. 2 (Springer-Verlag, 1989),

The work was funded by the U.S. Army Engineering and Housing Support Center (USAEHSC), under Project 4A162720A896, "Base Facility Environmental Quality"; Work Unit NN-TH9, "Advanced Methods for Evaluating/Monitoring Training Land Soil Resources." The USAEHSC technical monitor was Mr. Donald M. Bandel, CEHSC-FN.

The research was performed by the Environmental Division (EN) of the U.S. Army Construction Engineering Research Laboratory (USACERL). Dr. Edward W. Novak is Acting Chief of USACERL-EN.

COL Everett R. Thomas is Commander and Director of USACERL, and Dr. L.R. Shaffer is Technical Director. 
CONTENTS

SF298

FOREWORD

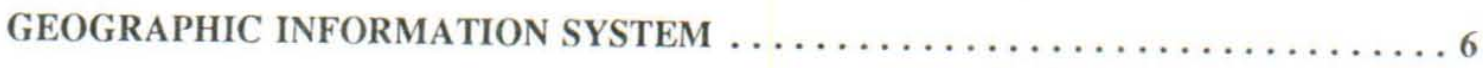

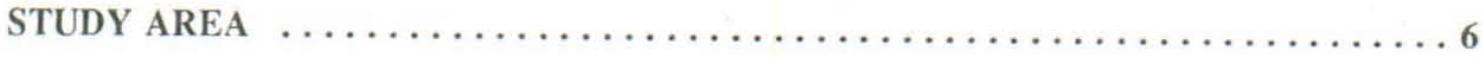

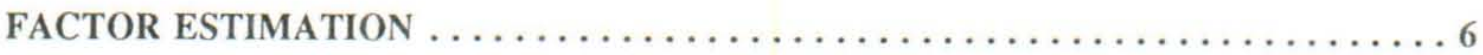

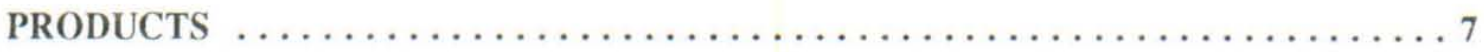

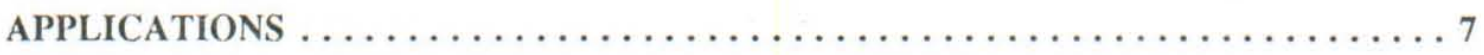

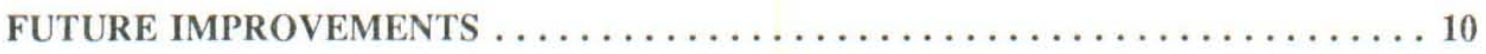

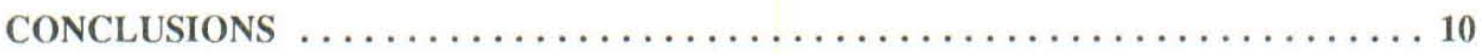

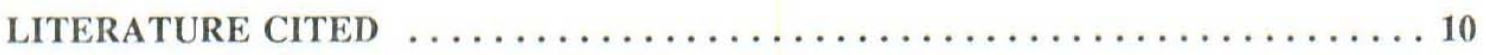

DISTRIBUTION 


\section{An Erosion-Based Land Classification System for Military Installations}

\section{STEVEN D. WARREN \\ VICTOR E. DIERSING \\ PAMELA J. THOMPSON \\ WILLIAM D. GORAN}

US Army Construction Engineering Research Laboratory

Environmental Division

PO Box 4005

Champaign, Illinois 61820, USA

ABSTRACT / The universal soil loss equation (USLE) has been integrated with a geographic information system known as the geographical resources analysis support system (GRASS) to create a land classification system for use by military trainers and land managers to minimize the environmental impacts of military training activities. The USLE pro- vides an estimate of current average annual sheet and rill erosion based upon factors representing climate, soil erodibility, topography, cover, and conservation support practices. The erosion estimate is compared to erosion tolerance values to produce an expression of the current erosion status. An index of inherent site erodibility is also achieved through manipulation of the USLE. Based on published soil surveys, satellite imagery, and ground-truth vegetation transects, data layers are created within GRASS for each of the component factors of the USLE. Appropriate mathematical operations are performed with the data layers, and color-coded maps are produced that represent the erosion status and erodibility index for each $50-\mathrm{m} \times 50-\mathrm{m}$ area of soil surface. These maps aid military trainers and land managers in scheduling appropriate kinds and intensities of military training activities.
In recent years, there has been a growing interest within the military community regarding the environmental condition of military training areas that have supported intensified training activities, particularly armored vehicle training (Diersing and Severinghaus 1984, Eriksson 1976, Goran and others 1983, Johnson 1982, Severinghaus and Goran 1981, Severinghaus and others 1979, Stewart and others 1987). Of particular concern to military trainers and land managers is the potential for damage to vegetation and soil and subsequent soil erosion (Coler 1987, Marsh 1986). As the frequency and intensity of military training increases and the soil surface becomes increasingly disturbed, the protective vegetation may be lost and soil erosion accelerated. If allowed to continue unchecked, extensive damage from gullying, sedimentation, and flooding may occur. Such damage is not only expensive to repair, but also diminishes the realism and longevity of military training lands and jeopardizes the safety of soldiers and equipment. In order to minimize maintenance costs and ensure the long-term utility of military training lands, it is necessary to inventory and classify the lands relative to their environmental condition and their ability to sustain various kinds and intensities of military training in the future.

Many existing land capability classification systems, such as the one developed by the US Department of

KEY WORDS Geographic information system; Universal soil loss equation; Remote sensing: Satellite imagery: Erodibility index; Erosion status
Agriculture, Soil Conservation Service (Klingbiel 1958), are qualitative in nature and are based upon agronomic land uses. As such, they have only limited applicability to military needs and concerns. Soil erosion, however, is a quantifiable variable, the consequences of which are easily understood by military trainers and natural resource managers. The most widely accepted, user-friendly erosion prediction model currently available is the universal soil loss equation (USLE) (Wischmeier and Smith 1978). The equation has the form:

$$
A=R \times K \times L S \times C \times P
$$

and provides an estimate of current average annual sheet and rill erosion $(A)$ as the product of factors representing climate $(R)$, soil erodibility $(K)$, topography $(L S)$, cover $(C)$, and conservation support practices $(P)$. Although not a part of the equation per se, a soil loss tolerance $(T)$ factor is also commonly used in conjunction with the USLE. The USLE is not without limitations, particularly when extended to nonagronomic environments (Blackburn 1980). However, when used with due caution, the USLE can be a valuable decision-making tool for land managers (Wischmeier 1976).

The components of the USLE are geographic in nature, thus lending themselves to manipulation by computerized geographic information systems (GIS). Integrations of the USLE with GIS have been accomplished for agricultural lands (Gilliland and BaxterPotter 1987, Spanner and others 1982). The objective 
of our research was to integrate the USLE with satellite imagery and GIS in order to create an automated, erosion-based land classification system for nonagricultural lands, particularly military training lands. It is beyond the scope and intent of this article to evaluate the accuracy and technical limitations of the USLE, remote imagery interpretation, and GIS systems. Readers interested in those topics are referred to Wischmeier (1976), Campbell (1987), and Walsh and others (1987), respectively.

\section{Geographic Information System}

Geographic information systems are designed to store, manipulate, analyze, and display spatial data derived from a variety of cartographic and thematic sources. The GIS selected for this project was the geographic resources analysis support system (GRASS) (Westervelt and others 1987), a public domain system developed by the US Army Corps of Engineers, Construction Engineering Research Laboratory. The cartographic and thematic data needed for this study were converted to 50-m grid-cell (raster) format prior to analysis. Grid cells within each data layer represented the respective physical land attributes of $50-\mathrm{m}$ $\times 50-\mathrm{m}$ areas on the ground.

\section{Study Area}

The site selected for study was the Fort Hood Military Reservation near Killeen, Texas. Fort Hood encompasses approximately 86,700 ha in central Texas of which about 53,400 ha are intensively used for armored vehicle maneuvers (US Department of the Army 1978). Approximately 25.100 ha are used as an artillery impact area, while 8200 ha are included within the cantonment (built-up) area. Vegetation types include woodlands, scrublands, and grasslands. A long history of heavy grazing both before and after acquisition by the Army has undoubtedly contributed to the low seral plant communities that currently exist in many areas at Fort Hood.

\section{Factor Estimation}

$R$. Soil erosion is greatly influenced by the intensity and duration of precipitation events and by the amount and rate of resulting runoff. The $R$ factor is a quantitative expression of the erosivity of local average annual precipitation and runoff. It can be obtained from government land management agencies or from isoerodent maps published in a variety of sources (e.g., De Boodt and Gabriels 1980, Rogler and Schwert- mann 1981, Wischmeier and Smith 1978), or it can be calculated (Wischmeier 1959, Onchev 1985) or estimated (Arnoldus 1980) from local precipitation data. At Fort Hood, $R$ is approximately $4680 \mathrm{MJ} \times \mathrm{mm} \times$ $\mathrm{ha}^{-1} \times \mathrm{hR}^{-1} \times \mathrm{yr}^{-1}\left(275 \mathrm{ft}\right.$-tons $\times$ in. $\times 10^{-2} \times$ acre $^{-1} \times \mathrm{hR}^{-1} \times \mathrm{yr}^{-1}$ ) (Wischmeier and Smith 1978). Because $R$ is generally constant within an area the size of a military installation, there was no need to create a special data layer for this factor within GRASS.

$K$. This factor reflects the natural erodibility of soils. It is dependent upon soil texture, organic matter content, structure, and permeability. The $K$ factor for many soil series is published in local or regional soil surveys. In the absence of a soil survey, $K$ may be determined using a soil erodibility nomograph (Wischmeier and Smith 1978) and information from laboratory analyses of soil samples collected in the field. $K$ factors for the soil series occurring on Fort Hood were available in a county soil survey (McCaleb 1985). Values ranged from 0.01 to $0.05 \mathrm{t} \times \mathrm{hR} \times \mathrm{MJ}^{-1} \times$ $\mathrm{mm}^{-1}\left(0.10-0.37 \mathrm{t} \times \mathrm{hR} \times 10^{2} \times \mathrm{ft}_{-\mathrm{t}^{-1}} \times \mathrm{in}^{-1}\right)$, with larger numbers reflecting greater erodibility. Using these values, an existing soil series data layer was reclassed by assigning the $K$ values to the respective soils. The result was a $K$ data layer representing the relative erodibility of soils at Fort Hood.

$L S$. The rate of soil erosion by water is significantly affected by both the length and steepness of land slopes. The $L S$ factor provides a quantitative representation of these topographic effects. At Fort Hood, slope length and gradient were determined in the field at 320 points in a stratified random fashion according to soil series. Slope length was measured as the overland distance from the point of origin of runoff to a point where the slope gradient decreased sufficiently to cause deposition of suspended sediment or to a point where runoff entered a defined channel. The slope length and gradient values for each sampled point were entered into a slope effect chart (Wischmeier and Smith 1978) to derive a unitless $L S$ value. The soil series data layer was reclassed using a mean $I S$ value for each soil series, thus creating an $L S$ data layer. $L S$ values at Fort Hood ranged from 0.2 to 4.14 , with the higher values indicating greater erosion potential.

C. This factor reflects the degree of erosion protection afforded by various soil covers. On rangelands, $C$ is dependent upon the kind and amount of cover in contact with the soil, and the height and extent of vegetative canopy. In order to estimate $C$, a LANDSAT multispectral scanner (MSS) image (\#85087116251X0, 
July 20, 1986) was obtained for the Fort Hood area. A computer-generated, unsupervised classification was made of the image based upon spectral signatures in the green $(0.5-0.6 \mu \mathrm{m})$, red $(0.6-0.7 \mu \mathrm{m})$, and two near-infrared $(0.7-0.8 \mu \mathrm{m}$ and $0.8-1.1 \mu \mathrm{m})$ wavelength bands. This classification process resulted in 23 land-cover categories.

Whereas previous attempts to integrate the USLE with satellite imagery have lumped spectral categories into broad agronomic classes with predetermined $C$ factors (e.g., Gesch and Naugle 1984, Spanner and others 1982), we determined $C$ using information from 122 permanently established point-intercept vegetation transects sampled during July and August 1986. Cover values were determined by entering the vegetation data into a $C$-factor table for permanent pasture, rangeland, and idle land (Wischmeier and Smith 1978). Each of the spectrally recognized landcover categories was defined according to the mean $C$ value of the transects representing that category. Land-cover categories at Fort Hood had $C$ factors ranging from 0.02 to 0.17 .

The $C$ factors, as well as the resulting erosion estimates, may be considered conservative, since they do not account for the physical disturbance caused by military training maneuvers. Research does not currently exist to establish $C$ for lands disturbed by military training activity.

$P$. This factor is a quantitative expression of the mitigating effect that conservation-support practices (e.g., contour tillage, strip cropping, terraces, etc.) have on the erosion process. Such conservation practices, however, are generally incompatible with military training. Therefore, $P$ was assigned a constant value of 1 , such that it had no effect on the erosion estimate provided by the USLE.

$T$. Although not actually a component of the USLE, $T$ is nonetheless an important element in the development of an erosion-based land classification system. It is an expression of the soil loss tolerance, or the amount of soil erosion that can be sustained on an annual basis without causing significant reductions in long-term plant productivity. It is dependent upon locally intrinsic rates of soil formation and soil depth. Annual soil loss tolerance values generally range from 2.2 to 11.2 tha ( $1-5$ t/acre). $T$ factors are often published in soil surveys but may also be obtained from government land management offices or may be estimated based upon the rooting depth of the soil (McCormack and others 1982). Using published $T$ values (McCaleb 1985), a $T$ data layer for Fort Hood was created by reclassing the soil series data layer.

\section{Products}

By itself, the annual soil loss estimate $(A)$ provided by the USLE is of little practical value in developing a land classification scheme. An erosion status or ratio of estimated soil loss to soil loss tolerance is a more accurate index from which to evaluate the condition of the land, hence the equation

$$
\text { Erosion status }=(R \times K \times L S \times C \times P) / T
$$

The solution to this equation was produced by performing the mathematical operations within GRASS on a cell-by-cell basis. For Fort Hood, this involved approximately 352,000 separate calculations, each with the potential for a different answer. The resulting data layer was reclassed into six categories, each reflectin. range of erosion status values (Figure 1). Erosit status values less than $90 \%$ indicate that current loss estimates are safely below soil loss tolerance, and therefore represent varying degrees of satisfactory soil erosion status. Lands included in the third category $(90 \%-109 \%)$ are considered marginal, while lands with erosion status values greater than $110 \%$ depict areas of increasingly unsatisfactory condition.

Another variable of interest to the military land manager is the inherent erosion potential of the land. The only component of the USLE that is altered from year to year by man's use of the land is the vegetative cover factor or $C$ factor. Once determined, all other factors remain constant for any given grid-cell. By substituting $T$ for $A$ in the USLE, and solving for the reciprocal of $C$, the equation becomes

$$
E I=(R \times K \times L S \times P) / T
$$

The product, $E I$, can be considered an erodibility index. Areas with erodibility index values greater than 8 are considered highly erodible land (Benbrook 1988). At Fort Hood, EI values ranged from 2 to 100 (Figure 2).

\section{Applications}

A land classification system based upon soil erosion has a broad range of applications that are of potential value to military trainers and land managers. They include:

1. Land condition inventories. Color-coded maps can be provided that graphically illustrate the current erosion status, erodibility index, or any of the USLE component data layers, thus providing a visual inventory of the land condition or characteristics. In addition, GRASS can be used to produce a numerical or 


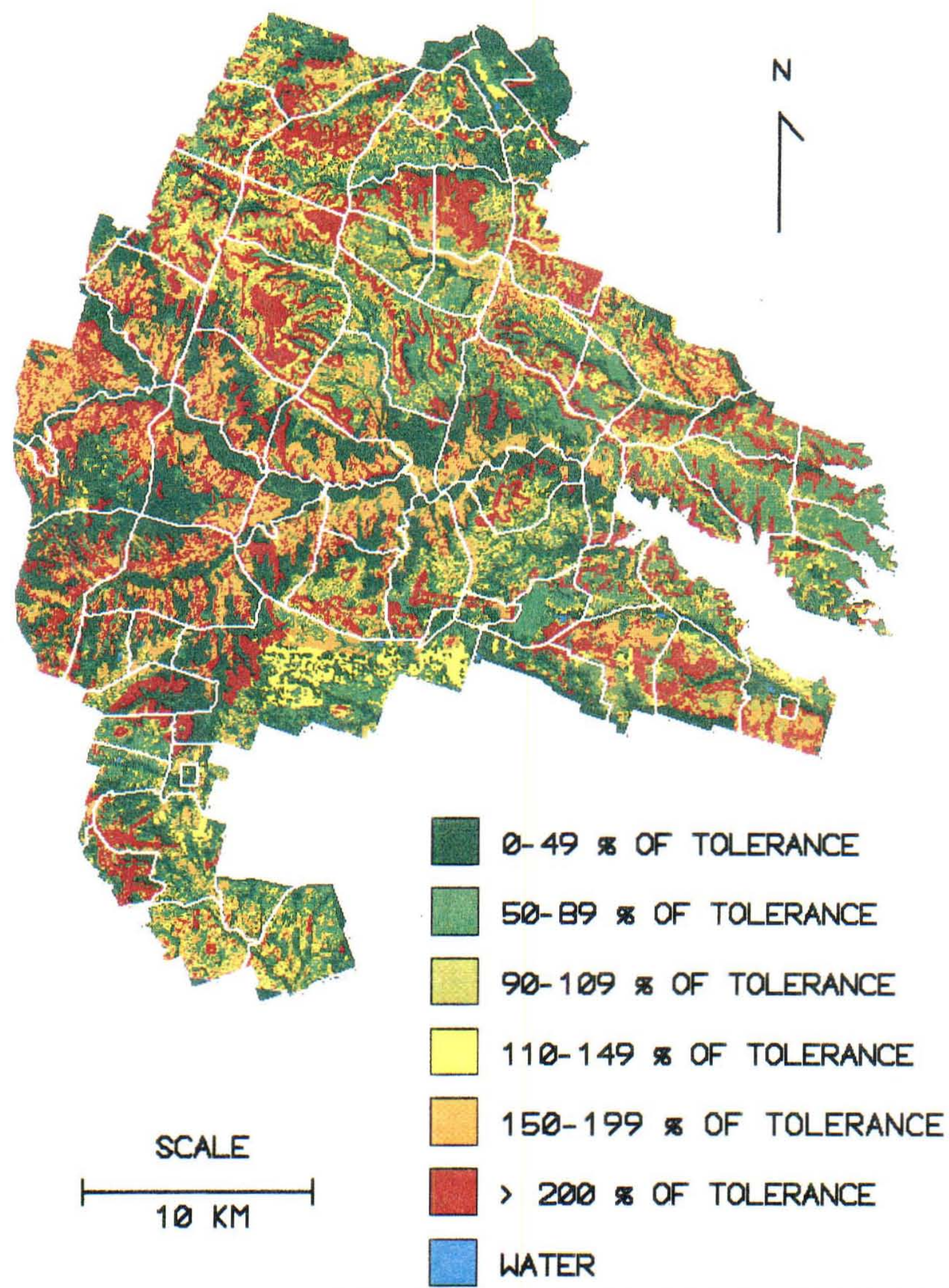

Figure 1. Erosion status map for Fort Hood, Texas. Erosion status is the ratio of estimated soil loss to the level of soil loss tolerance. Values less than $90 \%$ indicate that current soil erosion estimates are safely below tolerance limits. Areas in the $90 \%-109 \%$ range are marginal; values $110 \%$ and greater reflect levels of increasingly unsatisfactory soil erosion status. Training areas are bordered in white. 


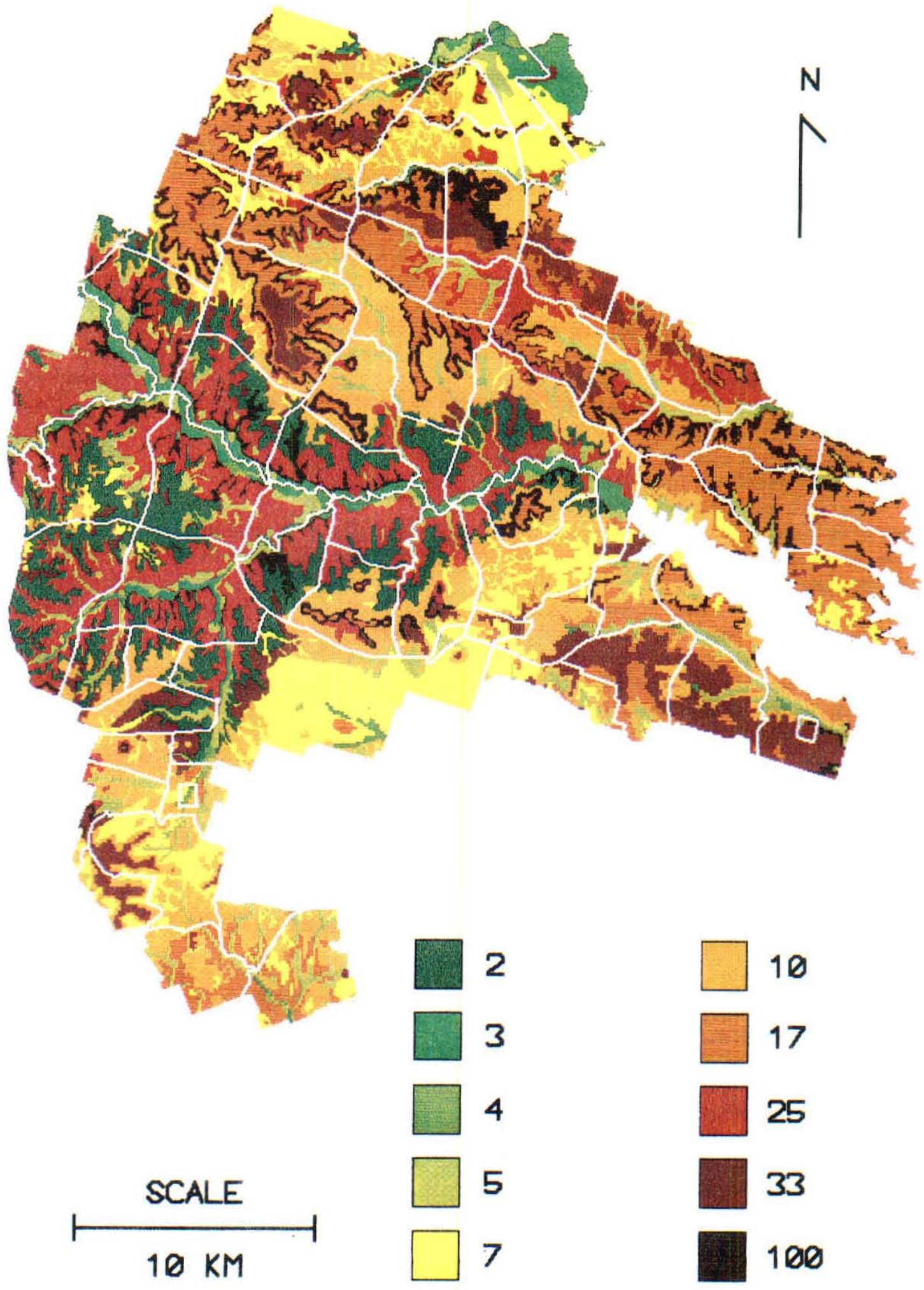

Figure 2. Erodibility index map for Fort Hood, Texas. Index values have been rounded to the nearest whole number. Small values indicate low erosion potential; soils with values greater than 8 are considered highly erodible. Training areas are bordered in white. 
tabular accounting of the extent of various categories within a given data layer. Comparisons of maps or reports of the erosion status data layer from year to year can reveal trends of improving or declining land condition.

2. Training schedules. Based upon the spatial distribution of erosion status and erodibility index categories, various types of military training activities can be scheduled in areas most capable of sustaining them. Intensive activities such as tracked vehicle maneuvers should be scheduled to avoid severely degraded and highly sensitive areas. In addition, a mean erosion status or erodibility index can be calculated for individual training areas at a given military installation to facilitate scheduling based upon the ability of the respective areas to support military maneuvers.

3. Training area demarcation. The erodibility index data layer can be used to demarcate training areas at military installations such that the land included within each training area is relatively uniform in terms of its inherent capacity to withstand training pressure. This will greatly simplify the management and scheduling of training areas.

4. Land rehabilitation. The erosion status data layer is useful in identifying areas that are potentially overused or badly degraded and that are in need of rest or some form of land rehabilitation treatment. These areas should be removed from training schedules until their condition has improved to the point where they can again support training activity without exceeding tolerable levels of soil loss.

5. Land acquisition. Both the erosion status and the erodibility index can provide valuable criteria for evaluating sites proposed for acquisition. Lands identified as badly degraded or highly erodible should not be considered for purchase or lease.

\section{Future Improvements}

Although the erosion-based land classification system is a valuable land management tool in its present form, there are several components that may be improved through additional research. For example, $L S$ values are presently assigned as an average for each soil series. Using high-resolution digital elevation data, however, it may be possible to estimate $L S$ values on a cell-by-cell basis. Such an improvement would add considerable accuracy to the erosion status and erodibility index data layers, particularly for soils that cover a wide range of slope gradients.

Improvement of the land-cover $C$ values may be possible with the use of alternative sources of remotely sensed imagery. LANDSAT thematic mapper imagery and SPOT imagery can improve the grid-cell resolution to $30 \mathrm{~m}$ or $20 \mathrm{~m}$, respectively. The LANDSAT thematic mapper and other sources provide electromagnetic spectral bands that are unavailable from the LANDSAT multispectral scanner. The use of the additional bands, plus techniques such as band ratios, may enhance the user's ability to accurately identify and differentiate between land-cover categories.

Advances in erosion modeling will also add significantly to the utility of the classification system. The universal soil loss equation is undergoing revisions in the methods used to calculate the $L S$ and $C$ factors (Renard 1987). In addition, an alternative to the USLE, currently being developed by the US Department of Agriculture, Agricultural Research Service, is scheduled for general release in 1992 (Foster and Lane 1987).

\section{Conclusions}

Many of man's activities, including military training, have the potential to adversely affect the environment. As stewards of the land, it is our responsibility to mitigate these impacts to the best of our ability. The land classification system described herein incorporates state-of-the-art erosion modeling, remote sensing, and geographic information processing. While none of these technologies is perfect, their integration provides a graphic, quantifiable approximation of the sensitivity and current condition of land resources as they relate to soil erosion. Although developed primarily to address military land management concerns, the system should have utility for managers of nonmilitary lands as well.

\section{Literature Cited}

Arnoldus, H. M. J. 1980. An approximation of the rainfall factor in the universal soil loss equation. Pages 127-132 in M. De Boodt and D. Gabriels (eds.), Assessment of erosion. John Wiley \& Sons, Chichester, England.

Benbrook, C. M. 1988. First principles: The definition of highly erodible land and tolerable soil loss. Journal of Soil and Water Conservation 43:35-38.

Blackburn, W. H. 1980. Universal soil loss equation and rangelands. Pages 588-597 in Proceedings of the symposium on watershed management '80, July 21-23, 1980. Boise, Idaho. American Society of Civil Engineers, New York, New York.

Campbell, J. B. 1987. Introduction to remote sensing. Guilford Press, New York. 551 pp.

Coler, U. V. 1987. Topographical conservation measures and cultivation on military training areas. Pages 99-104 in Proceedings - NATO committee on the challenges of modern 
seicty semina, November 28-30, 1984. Sis'sterterg. The Netherlands. Blue Book 159. Preservation of flora and fauna in military training areas. IS Army Construction Engineering Research Laboratory Conlerence Proceedings N-87/09. Champaign, Illinois.

De Boodt, M., and 1). (Gabriels (editors). 1980. Assessment of erosion. John Wiley \& Sons, Chichester, England. 563 pp.

Diersing, V. E., and W. D. Severinghaus. 1984. The effects of tactical vehicle training on the lands of Fort Carson, Colorado-an ecological assessment. US Army Construction Engineering Research Laboratory Technical Report N-85/03. Champaign, Illinois. 46 pp.

Eriksson, J. 1976. Influence of extremely heavy traffic on clay soil. Grundförbättring 27:33-51.

Foster, G. R., and L. J. Lane (compilers). 1987. User requirements: USDA - water erosion prediction project (WEPP). US Department of Agriculture, Agricultural Research Service, National Soil Erosion Laboratory Report No. 1. West Lafayette, Indiana. $43 \mathrm{pp}$.

Gesch, D. B., and B. I. Naugle. 1984. An analysis of the utility of I.ANDSAT thematic mapper data and digital elevation model data for predicting soil erosion. Pages 260-265 in M. M. Klepfer and D. B. Morrison (eds.), 10th international symposium on machine processing of remotely sensed data, June 12-14, 1984. Purdue University, West Lafayette, Indiana.

Gilliland, M. W., and W. Baxter-Potter. 1987. A geographic information system to predict non-point source pollution potential. Water Resources Bulletin 23:281-291.

Goran, W. D., L. L. Radke, and W. D. Severinghaus. 1983. An overview of the ecological effects of tracked vehicles on major US Army installations. US Army Construction Engineering Research Laboratory Technical Report N-142. Champaign, Illinois. 75 pp.

Klingbiel, A. A. 1958. Soil survey interpretation-capability groupings. Soil Science Society of America Proceedings 22:160163.

Johnson, F. L. 1982. Effects of tank training activities on botanical features at Fort Hood, Texas. Southwest Naturalist 27:309-314.

Marsh, J. O. 1986. Memorandum for the Chief of Staff, US Army, Subject: Management of natural resources on army land. April 24, 1986. Washington, DC.

McCaleb, N. L. 1985. Soil survey of Coryell County, Texas. US Department of Agriculture, Soil Conservation Service. Government Printing Office, Washington, DC. 129 pp.

McCormack, D. E., K. K. Young, and L. W. Kimberlin. 1982. Current criteria for determining soil loss tolerance. Pages 95-111 in D. M. Kral (ed.), Determinants of soil loss tolerance. American Society of Agronomy Spccial Publication 45. Madison, Wisconsin.

Onchev, N. G. 1985. Universal index for calculating rainfall erosivity. Pages 424-431 in S. A. El-Swaify, W. C. Moldenhauer, and A. Lo (eds.), Soil erosion and conservation. Soil Science Society of America, Ankeny, Iowa.

Renard, K. G. 1987. Present and future erosion prediction tools for use in pinyon-juniper communities. Pages 505-512 in R. L. Everett (ed.), Proceedings-pinyon-juniper conference, January 13-16, 1986. Reno, Nevada. ISDA Forest Service Gencral Techuical Repon IN T:215. Ogden, Utah.

Rogler, V. H., and U. Schwertmann. 1981. Frosivität der niederschläge und isoerodentkarte bayerns. Zeitschrift für Kulturtechnik und Flurbereinigung 22:99-112.

Severinghaus, W. D., and W. D. Goran. 1981. Effects of tactical vehicle activity on the mammals, birds, and vegetation at Fort Lewis, Washington. US Army Construction Engineering Research Laboratory Technical Report N-116. Champaign, Illinois. 45 pp.

Severinghaus, W. D., R. E. Riggins, and W. D. Goran. 1979. Effects of tracked vehicle activity on terrestrial mammals, birds and vegetation at Fort Knox, KY. US Army Construction Engineering Research Laboratory Special Report N-77. Champaign, Illinois. 64 pp.

Spanner, M. A., A. H. Strahler, and J. E. Estes. 1982. Soil loss prediction in a geographic information system format. Pages 89-102 in Papers selected for presentation at the sixteenth international symposium on remote sensing of environment, June 2-9, 1982. Buenos Aires, Argentina. Environmental Research Institute of Michigan, Ann Arbor, Michigan.

Stewart, J. A., A. T. Downs, and G. A. Stones. 1987. The impact of military training in Canada on indigenous flora and fauna. Pages 107-124 in Proceedings-NATO committee on the challenges of modern society seminar, November 28-30, 1984. Soesterberg, The Netherlands. Blue Book 159, Preservation of flora and fauna in military training areas. US Army Construction Engineering Research Laboratory Conference Proceedings N-87/09. Champaign, Illinois.

US Department of the Army. 1978. Training land. Training Circular 25-1. Washington, DC. $166 \mathrm{pp}$.

Walsh, S. J., D. R. Lightfoot, and D. R. Butler. 1987. Recognition and assessment of error in geographic information systems. Photogrammetric Engineering and Remote Sensing 53:1423-1430.

Westervelt, J. D., M. J. Shapiro, S. J. Bradshaw, J. Bozack, N. Chandra, W. D. Goran, K. J. Griffin, A. Heekin, M. O. Johnson, M. S. Larson, R. C. Lozar, M. V. Martin, K. A. Norman, C. O'Neil, M. F. O'Shea, and L. Van Warren. 1987. Geographical resources analysis support systemGRASS, Version 2.0. US Army Construction Engineering Research Laboratory ADP Report N-87/22. Champaign, Illinois.

Wischmeier, W. H. 1959. A rainfall erosion index for the universal soil loss equation. Soil Science Society of America Proceedings 23:246-249.

Wischmeier, W. H. 1976. Use and misuse of the universal soil loss equation. Joumal of Soil and Water Conservation 31:5-9.

Wischmeier, W. H., and D. D. Smith. 1978. Predicting rainfall erosion losses - a guide to conservation planning. US Department of Agriculture, Agriculture Handbook 537. Government Printing Office, Washington, DC. 58 pp. 